\title{
Pasture production and liveweight gain from cocksfoot-subterranean clover pastures grazed at two stocking rates and closed at different times during spring
}

\author{
S. ATES, R.J. LUCAS and G.R. EDWARDS \\ Agriculture Group, Agriculture and Life Sciences Division, PO Box 84 \\ Lincoln University, Lincoln \\ atess@lincoln.ac.nz
}

\begin{abstract}
The effect of stocking rate (8.3 (low) and 13.9 (high) ewes + twin lambs/ha) and time of closing in spring on lamb liveweight gain, pasture production and subterranean clover seedling densities was monitored over 2 years for a dryland cocksfoot-subterranean clover pasture in Canterbury. In both years, lambs grew faster $(\mathrm{g} / \mathrm{head} / \mathrm{d})$ in spring at low $(327 ; 385)$ than high $(253 ; 285)$ stocking

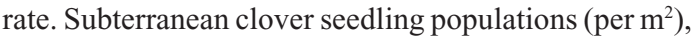
measured in autumn after grazing treatments in the previous spring, were greater at low (2850) than high (2500) stocking rate and declined with later closing dates $(3850,2950,2100$ and 1700 at 2, 4, 6, 8 weeks after early flowering). Seedling populations measured in autumn after grazing treatments in the second spring were unaffected by stocking rate (1290 low and 1190 high) but declined with later closing dates (1470, 1320 and 940). The effect of stocking rates and closing dates in spring of year 1 on pasture and clover production in the following autumn was similar to the effects on seedling numbers. However, clover production in the following spring was not affected by stocking rates or closing dates imposed a year earlier.
\end{abstract}

Keywords: cocksfoot, Dactylis glomerata, closing date, liveweight gain, seedling density, sheep grazing, stocking rate, subterranean clover, Trifolium subterraneum

\section{Introduction}

Subterranean clover (Trifolium subterraneum L.) is an important annual legume for dryland pastures in New Zealand. Subterranean clover provides nitrogen for companion grasses such as cocksfoot (Dactylis glomerata L.) and high quality feed for lactating ewes and their lambs (Brown et al. 2006). For example, liveweight gains of 300-400 g/head/day have been recorded for twin lambs grazing subterranean clover based pastures on dry stony soil even at high stocking rates (Ates et al. 2006).

However, the intensive grazing that occurs under high stocking rates may come at a cost in terms of reduced subterranean clover seed production as sheep consume leaves, runners, flowers and seed burrs (Ates et al. 2006). In turn, this may lead to low seedling establishment in the following autumn and subsequent reductions in clover dry matter production in spring. Grazing management in spring to achieve both liveweight gain and seed production objectives is thus an important challenge for farmers.

In paddocks where subterranean clover populations are low and unproductive, farmers may look to boost clover populations by either lax grazing or by spelling pastures earlier than normal lamb weaning dates. This more lenient spring management should increase flower and seed burr numbers, enabling the seed bank to be replenished. However, decisions for differential management and closing dates are not well supported by quantified data (Ates et al. 2006). Thus, as part of a package of work on the development of guidelines on subterranean clover grazing management which are compatible for both pasture persistence and lamb production the objectives of this study were:

1) To quantify the effect a low versus high ewe stocking rate in spring on twin lamb and ewe liveweight gain and on pasture production in the following year.

2) To quantify the effect of closing date in spring on seedling emergence and pasture production in the following year.

\section{Materials and Methods}

\section{Experimental site}

The experiment was conducted in a 2.9 ha paddock at Ashley Dene, the Lincoln University dryland research farm located near Lincoln, Canterbury. The soil type is a Lismore very stony silt loam. Soil tests taken on 30 July 2006 gave: $\mathrm{pH}$ (in water) 6.4, Olsen P 18, Ca 8.6 m.e./ $100 \mathrm{~g}$, K 0.75 m.e./100g, Mg 0.73 m.e./100g, $\mathrm{SO}_{4} 4 \mathrm{ug} /$ $\mathrm{g}$ and $\mathrm{Na} 0.13$ m.e. $/ 100 \mathrm{~g}$. Ashley Dene has a mean annual rainfall of $625 \mathrm{~mm}$. Rainfall and air temperatures at Ashley Dene during the experimental grazing period (August 2006 to May 2008) are given in Figure 1. It is noteworthy that rainfall through October 2006 to January 2007 was above average. Temperature was also lower than average from December 2006 to February 2007.

The paddock was cultivated and split into four blocks in September 2002. Five seed mixtures of 'Aries HD' perennial ryegrass (Lolium perenne L.) infected with AR1 endophyte, 'Vision' cocksfoot and 'Demand' white clover (Trifolium repens L.) were sown in a randomised block design on 7 October 2002. Perennial ryegrass was sown at $0,5,10$ or $15 \mathrm{~kg} /$ ha with $2 \mathrm{~kg} / \mathrm{ha}$ cocksfoot and 
Figure 1 a) Mean monthly temperature (- - ) and monthly rainfall ( $\boldsymbol{\square})$ at Ashley Dene from 1 September 2006 to 30 April 2008. Long term averages (2001-2008) are shown for temperature (-O-) and rainfall $(\square)$.

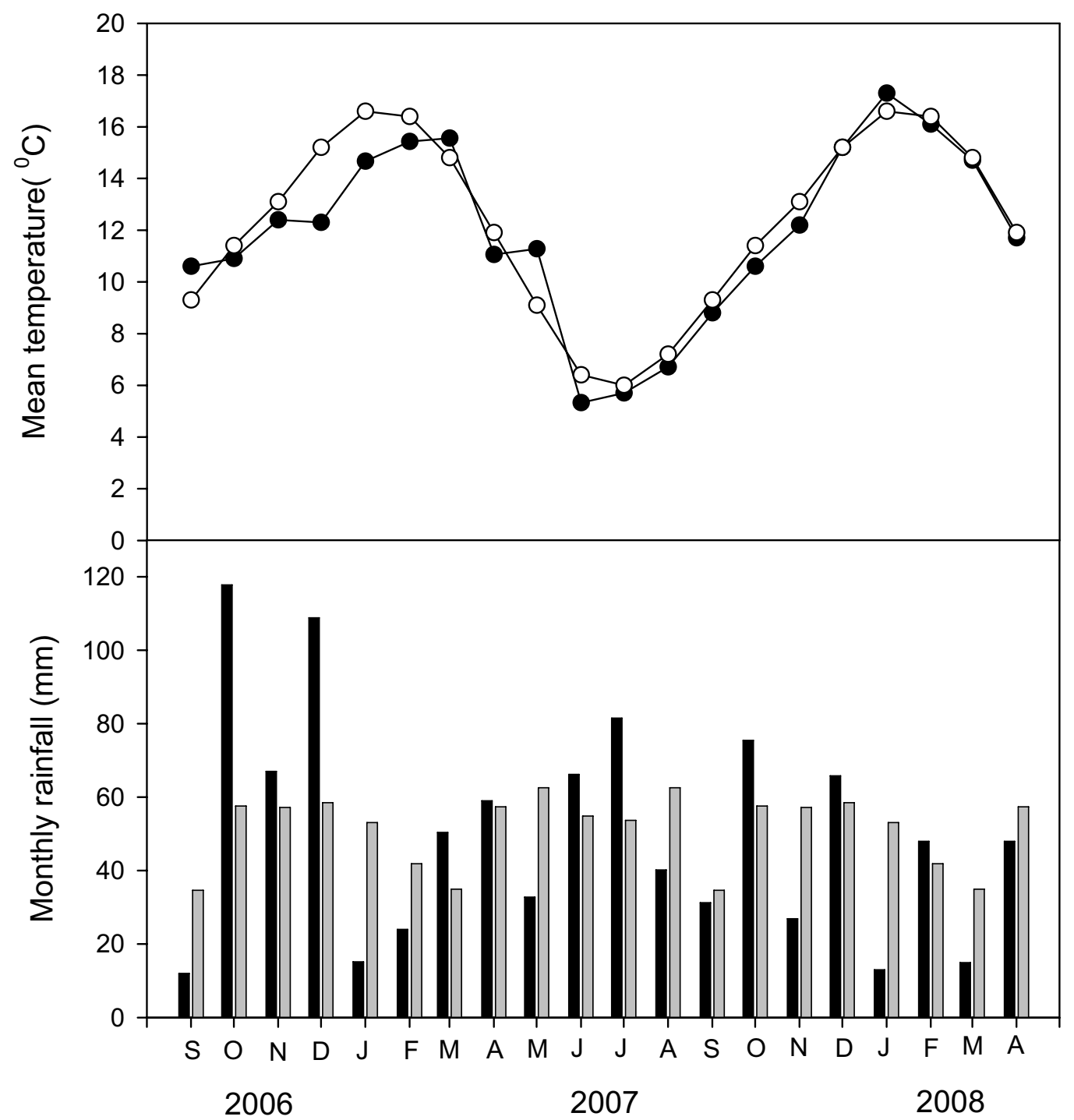

$2 \mathrm{~kg} / \mathrm{ha}$ white clover. A fifth treatment was sown at 10 $\mathrm{kg} / \mathrm{ha}$ ryegrass and $2 \mathrm{~kg} / \mathrm{ha}$ white clover without cocksfoot. The establishment and persistence of white clover was poor with white clover cover of $<0.1 \%$ in March 2005. All plots were direct drilled across the original $16 \mathrm{~m} \times 87 \mathrm{~m}$ main plots with $10 \mathrm{~kg} / \mathrm{ha}$ of subterranean clover $(5 \mathrm{~kg} / \mathrm{ha}$ 'Leura' and $5 \mathrm{~kg} / \mathrm{ha}$ 'Campeda') on 18 March 2005. Four strips, each $10 \mathrm{~m}$ wide were not drilled to act as controls. This gave 2 × 10 $m$ wide strips with no overdrilled subterranean clover in each main plot to provide an indication of the value of subterranean clover compared with the negligible white clover and resident annual cluster clover (Trifolium glomeratum L.)
Botanical composition was scored by visual estimates (\% cover) in five $1 \mathrm{~m}^{2}$ quadrats in each block on 25 September 2006. Based on this, the percentage composition (weighted means across areas with and without overdrilled subterranean clover) of the area was: $32.4 \%$ subterranean clover, $40.7 \%$ cocksfoot, $13.9 \%$ ryegrass, $0.1 \%$ white clover, $1.7 \%$ cluster clover, $1.7 \%$ annual weeds, $0.3 \%$ dicot weeds and $9.3 \%$ bare ground.

\section{Stocking rate treatment}

The paddock was fenced into four blocks and grazing treatments were imposed on three of the four original blocks in September 2006. The smaller area in the fourth block was used to run spare ewes and lambs which 
could be used as replacement animals if required. Each of the three larger blocks was split in half and allocated to main plot treatments of high (13.9 (range 13.2-14.8) ewes with twin lambs/ha) and low ( 8.3 ewes with twin lambs/ha) stocking rate treatments for spring 2006 and spring 2007. Coopworth ewes (mean initial LW=69 kg in 2006 and $63 \mathrm{~kg}$ in 2007) with Coopworth lambs (mean initial LW= $8.6 \mathrm{~kg}$ in 2006 and $6.8 \mathrm{~kg}$ in 2007) were randomly allocated to plots for spring grazing experiments. Spring grazing experiments ran for 77 days in 2006 from 19 September to 5 December and 88 days in 2007 from 23 August to 19 November. Both low and high stocking rate treatments were repeated on the same plots in each year.

Dry ewes were used to reduce pasture masses accummulated after weaning in all plots to approximately $900 \mathrm{~kg} \mathrm{DM} / \mathrm{ha}$. A total of 400 dry ewes were rotationally grazed from mid-January to mid-February in 2007 and from mid-January to end of January in 2008. Pastures were spelled from grazing to allow annual clovers to reestablish following autumn rains, then grazed with 18 hoggets/ha from 23 April until 2 June 2007 and with 21 hoggets/ha from 14 March to 29 April 2008. Plots were not grazed during winter to simulate normal spelling of lambing paddocks during winter.

All ewes and lambs were weighed during spring on 19 September, 16 October, 10 November and 5 December 2006 and 23 August, 16 October and 19 November 2007. Liveweight gain per head (g/head/day) and per hectare $(\mathrm{kg} / \mathrm{ha} /$ day $)$ were calculated for each stocking rate treatment.

Pasture mass (kg DM/ha) was measured weekly during each spring grazing period using a calibrated rising plate meter. A total of 100 rising plate meter readings were taken across each grazed main plot. Plate meter readings were calibrated by double sampling four $0.2 \mathrm{~m}^{2}$ quadrat cuts per plot each week. Herbage snip samples, representative of the pasture eaten by sheep, were collected randomly across the pasture in each stocking rate plot at weekly intervals. A sub sample was sorted for botanical composition and components were oven dried at $70^{\circ} \mathrm{C}$. Percentage botanical composition of snip samples on a dry weight basis was then calculated. The remaining bulk samples were analysed for metabolisable energy (ME) by NIRS.

Liveweight gain per head $(\mathrm{g} / \mathrm{d})$ and per ha $(\mathrm{kg} / \mathrm{ha} / \mathrm{d})$ were analysed by one-way ANOVA with repeated measures for each liveweight gain measurement period. Pasture mass, nutritive value and diet botanical composition were analysed by one-way ANOVA with three replicates at each date.

\section{Closing date treatments}

Small $3 \times 3 \mathrm{~m}$ sub-plots in each stocking rate treatment were fenced to exclude sheep at different times in spring to create time of grazing exclusion treatments. Grazing exclosure sub-plots in spring 2006 were located on plots originally sown with $10 \mathrm{~kg} / \mathrm{ha}$ ryegrass $+2 \mathrm{~kg} / \mathrm{ha}$ cocksfoot $+2 \mathrm{~kg} / \mathrm{ha}$ white clover and in spring 2007 were on plots sown with $5 \mathrm{~kg} /$ ha ryegrass $+2 \mathrm{~kg} / \mathrm{ha}$ cocksfoot $+2 \mathrm{~kg} / \mathrm{ha}$ white clover. These $3 \times 3 \mathrm{~m}$ sub-plots were installed on 10 October, 26 October and 15 November in 2006. The main area of pasture was grazed until weaning on 5 December 2006 and then spelled. In the second year, sub-plot fences were erected on 16 October and 1 November and pasture in all stocking rate main plots were spelled on 19 November 2007. In 2006 these dates corresponded approximately to 2, 4, 6 and 8 weeks after subterranean clover had started flowering and in 2007, the closing dates coincided with 3, 5 and 8 weeks after early flowering. Fences around exclosure plots were pulled down before the summer grazing each year and left open during the remainder of year.

Pasture production from each closing date treatment was measured using quadrat cuts inside $1 \mathrm{~m}^{2}$ exclosure cages. Cages were placed on 8 February 2007 and production was measured on 23 April 2007 (autumn production). Cages were placed on a new site on 2 June 2007 and production was measured on 31 August, 4 October and 6 November in 2007 (winter-spring produciton) from the same cage site. At each harvest, an area of $0.2 \mathrm{~m}^{2}$ under the cages was cut to a $20 \mathrm{~mm}$ stubble height with electric shears. After cutting, the same caged area was mown to $20 \mathrm{~mm}$ height and cages were replaced on the same sites. Sub samples were sorted into cocksfoot, ryegrass, annual grass weeds, subterranean clover, white clover, cluster clover, dicot weeds and dead material. Botanical composition samples were oven-dried at $70^{\circ} \mathrm{C}$ to a constant weight and then used to calculate composition on dry matter basis. As an indicator of effects of grazing management on seed production, subterranenan clover seedling numbers were counted in two randomly placed $0.01 \mathrm{~m}^{2}$ quadrats in each closing date treatment area on 2 June 2007 and 8 May 2008.

Pasture production and botanical composition were analysed by one-way ANOVA with three replicates at each date. Seedling numbers were analysed by one-way ANOVA with three replicates.

\section{Results}

\section{Stocking rate treatments}

Lamb liveweight gain per animal in each period was greater $(\mathrm{P}<0.05)$ at low than high stocking rate in both 2006 and 2007 (Table 1). Averaged over the entire spring grazing period lambs grew at $327 \mathrm{~g} / \mathrm{head} / \mathrm{d}$ and $385 \mathrm{~g} /$ head/d at the low stocking rate and $253 \mathrm{~g} / \mathrm{head} / \mathrm{d}$ and 285 $\mathrm{g} / \mathrm{head} / \mathrm{d}$ at the high stocking rate in 2006 and 2007 respectively. Final lamb liveweights were $34 \mathrm{~kg}$ and 40.5 
Table 1 Mean liveweight gain per individual lamb and ewe (g/head/day) over three periods in spring 2006 and two periods in spring 2007 under low (8.3) and high (13.9) stocking rates.

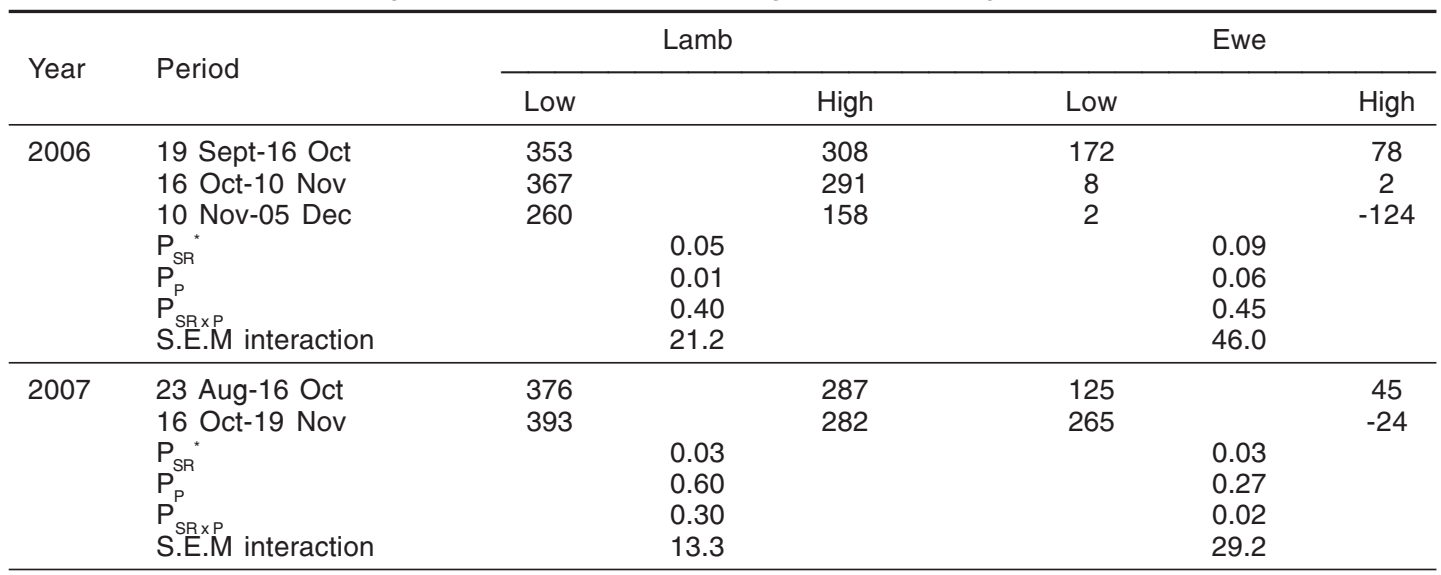

${ }^{*} \mathrm{P}$ values are from ANOVA for effects of stocking rate $(\mathrm{SR})$, period $(\mathrm{P})$ and interaction $(\mathrm{SR} \times \mathrm{P})$.

Table 2 Mean liveweight gain per ha for lambs and ewes (kg/ha/day) over three periods in spring 2006 and two periods in spring 2007 under low (8.3) and high (13.9) stocking rates.

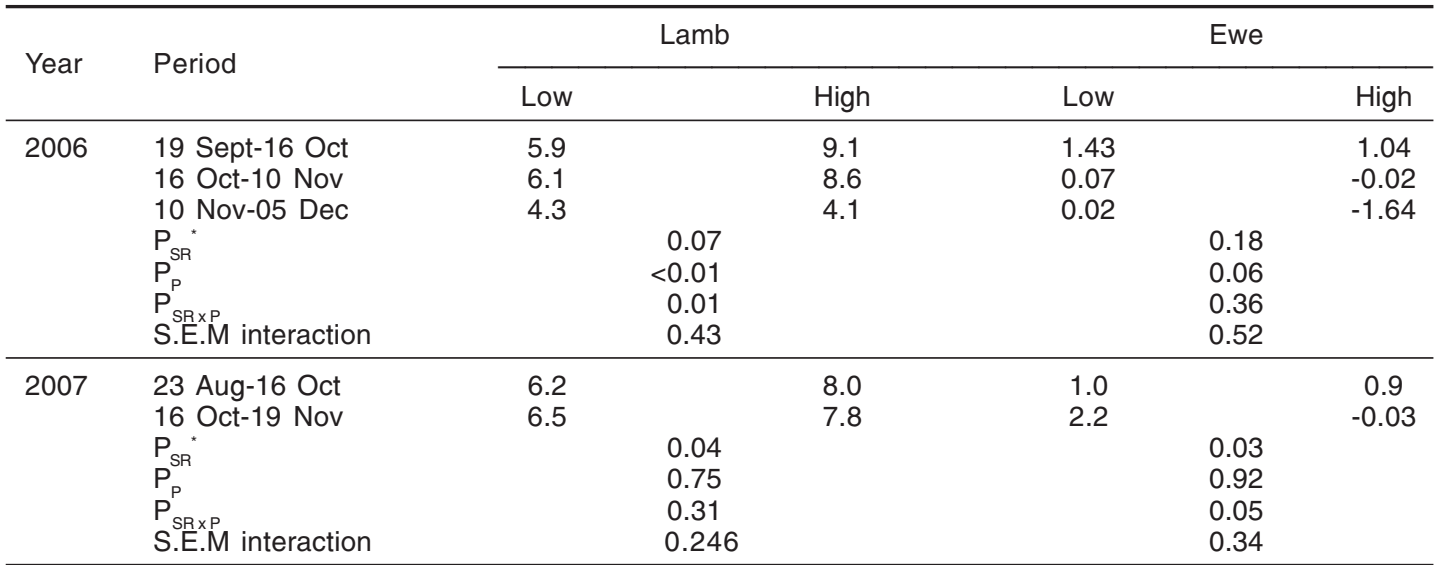

${ }^{*} \mathrm{P}$ values are from ANOVA for effects of stocking rate $(\mathrm{SR})$, period $(\mathrm{P})$ and interaction $(\mathrm{SR} \times \mathrm{P})$.

$\mathrm{kg}$ at the low and $29 \mathrm{~kg}$ and $32 \mathrm{~kg}$ at the high stocking rates in 2006 and 2007, respectively. Lamb liveweight gain per ha/d was greater at the high than low stocking rate in the first two periods in spring 2006 and in both periods in spring 2007 (Table 2).

Ewe liveweight gain per animal was greater at the low than high stocking rate in all periods in both years (Table 1). Ewes gained 4.9 and lost $0.9 \mathrm{~kg}$ at low and high stocking rate respectively in 2006, while ewes gained 15.5 and $1.6 \mathrm{~kg}$ at low and high stocking rate respectively in $2007(\mathrm{P}<0.05)$ (Table 1).

The low stocking rate treatments had a higher mean pasture mass than high stocking rate treatments in both years (Fig. 2). In spring 2007, pasture mass was lower than in 2006 at both stocking rate treatments due to the earlier start of the experiment with the aim of exploiting early spring subterranean clover production. The clover content of the pasture on offer was greater in the low than high stocking rate in both years, but the difference was only significant $(\mathrm{P}<0.05)$ at one date in 2006 compared with four dates in 2007. Clover content was also greater in 2007 than in 2006 at both stocking rates. Metabolisable energy content was greater at low than high stocking rate treatments in both years, fluctuating between 10.5 and 12.0 MJ ME kg/DM (Fig. 2). The difference between stocking rates was only significant at one date in each year $(\mathrm{P}<0.05)$.

\section{Closing date treatments}

There were more subterranean clover seedlings at low $\left(2820 / \mathrm{m}^{2}\right.$ in 2007 and $1290 / \mathrm{m}^{2}$ in 2008) than high (2480/ $\mathrm{m}^{2}$ in 2007 and $1190 / \mathrm{m}^{2}$ in 2008) stocking rate, although 
Figure 2 Weekly pasture mass (kg DM/ha) (a, b), percentage clover (c, d) and metabolisable energy of pasture (MJ ME/kg DM) (e, f) in spring 2006 and spring 2007 under low (- - ) and high (-O-) stocking rates. Bars represent the LSD above the period when the difference was significant $(\mathrm{P}<0.05)$.
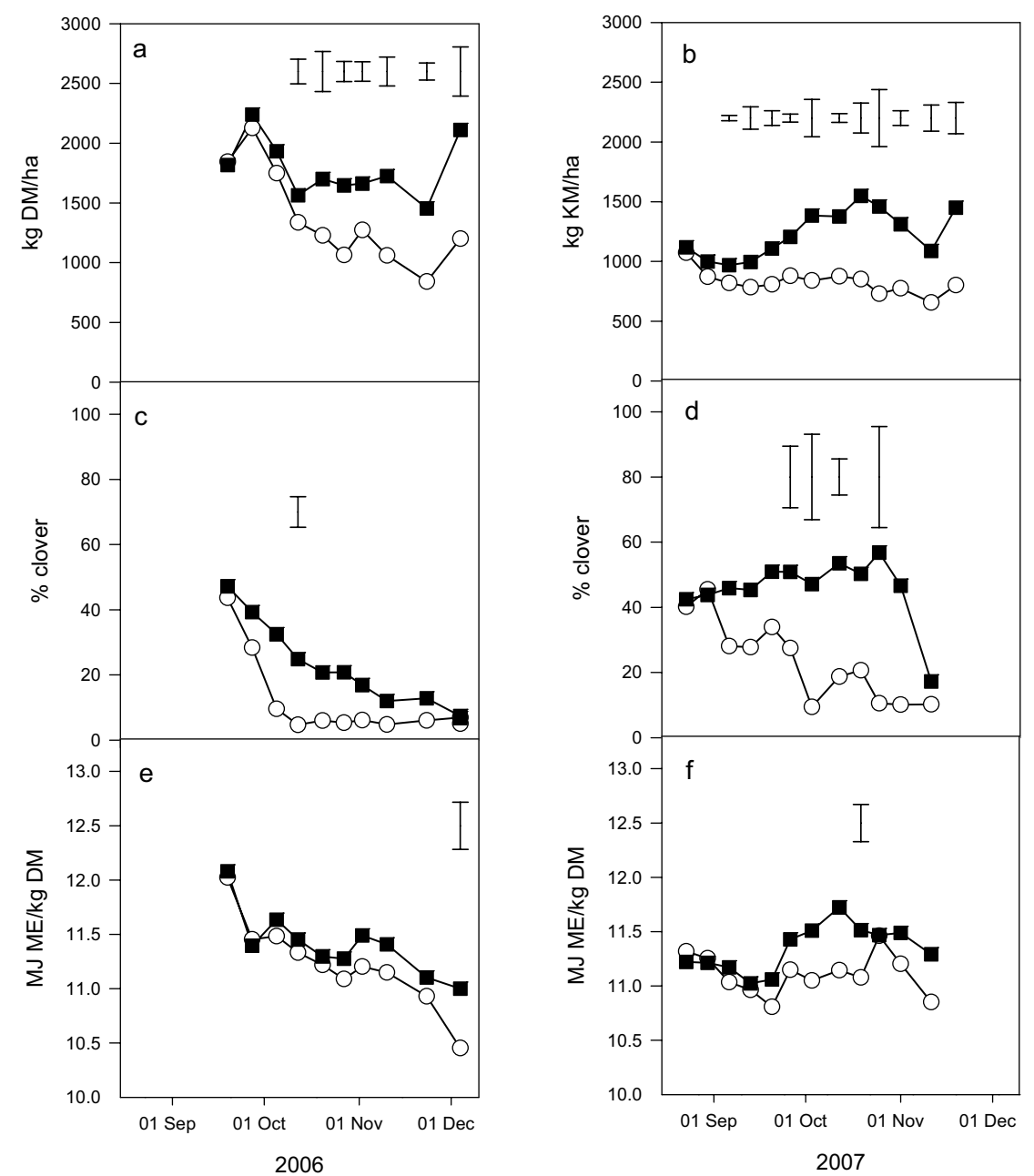

Figure 3 The effect of stocking rate (low vs. high) and closing date in spring 2006 and spring 2007 on established seedling numbers in (a) early winter 2007 and (b) late autumn 2008. Bars represent LSD for main effect of closing date $(P<0.05)$.
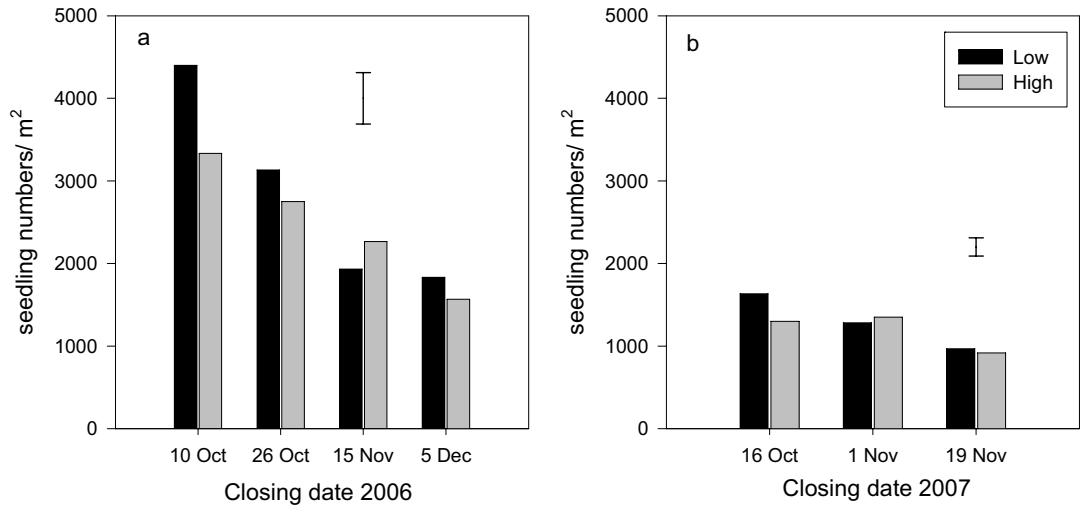
Figure 4 The effect of stocking rate (low vs. high) and closing date in spring 2006 on total $(\boldsymbol{\square}+\square)$ and total clover ( $)$ dry matter production in (a) autumn 2007 (2 February to 23 April) and in (b) winter-spring 2007 (2 June to 6 November). Bars represent LSD for main effect of closing date in autumn and stocking rate in winter-spring on clover production $(C P)$ and total pasture production $(T P)(P<0.05)$.

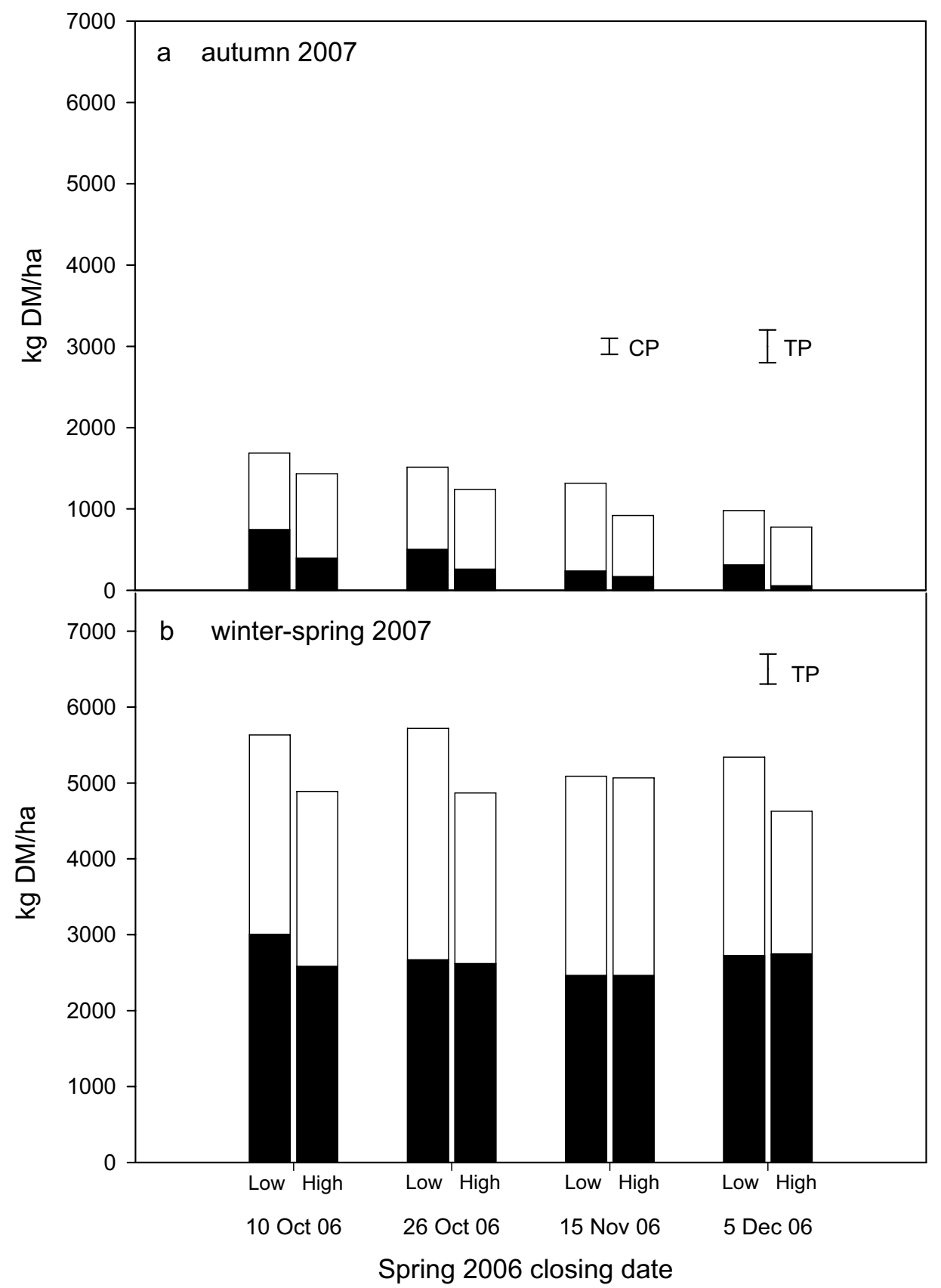

the difference was not significant $(\mathrm{P}>0.05)$ in either year. Earlier closing resulted in a greater number of subterranean clover seedlings established at both stocking rates in both years $(\mathrm{P}<0.05)$ (Fig. 3). Total autumn herbage and clover production in 2007 was greater at earlier closing dates $(\mathrm{P}<0.05)$ and in general, higher at low than high stocking rate, but this effect was not significant $(\mathrm{P}=0.21)$ (Fig. 4a). Total winter and spring pasture production was greater at low $(5450 \mathrm{~kg} \mathrm{DM} / \mathrm{ha})$ than high $(4860 \mathrm{~kg} \mathrm{DM} / \mathrm{ha})$ stocking rate $(\mathrm{P}<0.05)$, but earlier closing did not affect total pasture or clover production in spring 2007 (Fig. 4b). 


\section{Discussion}

This study confirms previous findings (Ates et al. 2006) that high growth rates of twin lambs $(>300 \mathrm{~g} / \mathrm{d})$ can be achieved on dryland pastures where subterranean clover is the main legume. The results here for lamb growth rate compare favourably with the high twin lamb growth rates of $407 \mathrm{~g} / \mathrm{head} /$ day reported by Muir et al. (2003), where both ewes and rams were selected for high progeny growth rate and the ewes and lambs grazed on a newly sown pasture of perennial ryegrass with white and subterranean clover which was maintained at 1800-2600 $\mathrm{kg} \mathrm{DM} / \mathrm{ha}$ at Poukawa, Hawkes Bay.

Lamb liveweight gains were higher at low than high stocking rate in both years. This probably reflects the greater proportion of clover on offer at low stocking rate leading to improved diet quality (Cosgrove \& Edwards 2007). The importance of clover on offer for lamb liveweight gain is highlighted by the lower growth rates at both high and low stocking rates in the third period in spring 2006. Clover content declined to below $10 \%$ and growth rates fell to 260 and $158 \mathrm{~g} /$ head/day at low and high stocking rate respectively. The stocking rate effect was similar to that reported by Ates et al. (2006). This was in spite of the high stocking rate treatment in the current study being lower than the study of Ates et al. (2006) (13.9 vs. 20 ewes/ha) and the wetter than average spring in 2006 in this study, leading to more sustained subterranean clover growth at both stocking rates.

Lower stocking rate and closing earlier in spring generally resulted in more subterranean clover seedlings in the following year confirming the potential value of early closing as a method to restore subterranean clover populations. However, it was notable that seedling numbers remained high in both years. Indeed, most were in excess of the $500-1000 / \mathrm{m}^{2}$ recommended for mixed pastures (Smetham 2003). Under drier spring conditions or in paddocks of lower initial subterranean clover population density, the value of earlier closing for restoring the subterranean clover seed bank might be expected to be greater. This was highlighted by the fact that continuous grazing until 19 November in spring 2007 (the drier of the two springs) suppressed seedling numbers in the following autumn into the recommended range (e.g. $500-1000 / \mathrm{m}^{2}$ ) whereas closing 19 days earlier resulted in $300-400 / \mathrm{m}^{2}$ more seedlings.

A feature of the results was the contrasting effects of closing date on pasture production in autumn and spring in the following year. Autumn clover production followed a similar trend to seedling numbers, with greater production at earlier closing dates. However, spring clover production was unaffected by closing date $(\mathrm{P}>0.05)$. This most likely reflects the change in morphology of clover plants between autumn and spring. In autumn when subterranean clover plants are a compact rosette, pasture production is likely to be heavily dependant on population density. In contrast runner growth in spring appeared to be able to compensate for the lower populations. In previous work, Prioul \& Silsbury (1982) reported that higher subterranean clover populations in pure swards had the highest growth rate soon after emergence but the relative importance of plant density declined as the season progressed. Low density subterranean clover communities showed an increasing crop growth rate during the season so that final yields were similar for pure swards of 428 and 4760 plants $/ \mathrm{m}^{2}$. At lower plant densities (e.g. $300-500 / \mathrm{m}^{2}$ ) than found in this study, spring clover production is likely to be reduced as there is less chance of the runner growth compensating for low populations and longer runners may also be more vulnerable to selective grazing (Ates et al. 2006).

\section{Conclusions}

Lactating ewes and their lambs quickly reduce the clover content of subterranean clover pastures in spring and in drier seasons this may cause marked reductions in seed production and subsequent seedling numbers, especially if pastures are grazed through to and after weaning. However on farms where ewes and lambs can be moved to lucerne (or other high nutritive value forages) from subterranean clover grass lambing paddocks in midOctober, seed production from subterranean clover should not be adversely affected. Identifying paddocks which have low subterranean clover populations in autumn and ensuring stock are moved from these early is likely to be the key strategy to increase subterranean clover.

\section{ACKNOWLEDGEMENTS}

The authors thank Colin Pettigrew and Malcolm Smith for help with stock work and Keith Pollock for help with environmental data collection. Funding for this project was provided by a New Zealand International Doctoral Research Scholarship to Serkan Ates.

\section{REFERENCES}

Ates, S; Brown, H.E.; Lucas, R.J.; Smith, M.C; Edwards, G.R. 2006. Effect of ewe stocking rate in spring on subterranean clover persistence and lamb liveweight gain. Proceedings of the New Zealand Grassland Association 68: 95-99.

Brown, H.E.; Moot, D.J.; Lucas, R.J.; Smith, M. 2006. Sub clover, cocksfoot and lucerne combine to improve dryland stock production. Proceedings of the New Zealand Grassland Association 68: 109-115.

Cosgrove, C.P.; Edwards G.R. 2007. Control of grazing intake. pp. 61-80. In: Pasture and Supplements for Grazing Animals Rattray, P.V.; Brookes, I.M.; Nicol, A.M. Eds New Zealand Society of Animal Production. 
Occasional Publication No 14

Muir, P.D.; Smith, N.B.; Lane, J.C. 2003. Maximising lamb growth rate - just what is possible in a high performance system. Proceedings of the New Zealand Grassland Association 65: 61-63.

Prioul, J.L.; Silsbury, J.H. 1982. A physiological analysis of the effect of sowing density on the growth rate of subterranean clover. Australian Journal of Agricultural Research 33: 213-22.

Smetham, M.L. 2003. A review of subterranean clover (Trifolium subterraneum L.): its ecology and use as a pasture legume. Advances in Agronomy 79: 303-350. 